\title{
GIS TECHNOLOGY AS A TOOL FOR PROTECTING LANDSCAPE AND CULTURAL VALUES IN SPATIAL PLANNING
}

\section{TECHNOLOGIA GIS NARZEDDZIEM OCHRONY KRAJOBRAZU I WARTOŚCI KULTUROWYCH W PLANOWANIU PRZESTRZENNYM}

DOI: $10.30540 /$ sae-2018-013

\begin{abstract}
The issue of a landscape protection is quite a significant element of municipal spatial policy. Currently, there is no legal obligation to implement, within the statutory activities of institutions responsible for the landscape protection, guidance documents prior to work on the development of the municipality. Space management, through planning a development and land use or the landscape protection, requires access to comprehensive and reliable information. The use of GIS technology in spatial analysis and monitoring changes in space, for the landscape and cultural values protection, provides opportunities to assist decisions on the destination and land use in spatial planning carried out using planning documents (A study of the conditions and directions of the spatial planning and the local zoning plan).
\end{abstract}

Keywords: landscape protection, GIS, spatial planning, planning documents

\section{Streszczenie}

W odniesieniu do polityki przestrzennej gmin, problematyka ochrony krajobrazu stanowi element dość znaczacy. Aktualnie brak jest prawnego obowiazku realizacji, w ramach dziatań statutowych instytucji odpowiedzialnych za ochrone krajobrazu, dokumentów o charakterze wytycznych wyprzedzajacych prace nad kierunkami rozwoju gminy. Zarzadzanie przestrzenia, przez planowanie rozwoju oraz sposobu zagospodarowania terenu lub ochrony krajobrazu wymaga dostępu do wszechstronnej $i$ wiarygodnej informacji. Wykorzystanie technologii GIS w ramach analiz przestrzennych oraz monitoringu zmian zagospodarowania przestrzeni na potrzeby ochrony krajobrazu $i$ wartości kulturowych daje możliwości wspomagajace decyzje dotyczace przeznaczenia i sposobu zagospodarowania przestrzeni w planowaniu przestrzennym, realizowanym za pomoca dokumentów planistycznych gmin (studium uwarunkowań $i$ kierunków zagospodarowania przestrzennego gminy i miejscowego planu zagospodarowania).

Slowa kluczowe: ochrona krajobrazu, GIS, planowanie przestrzenne, dokumenty planistyczne

\section{INTRODUCTION}

Municipal spatial policy, characterized through historical and cultural values and landscape protection is based on the Polish legal system, on the Act on Spatial Planning and Development [1] and the Construction Law act [2]. Both documents along with implementation rules are the foundations of an investment process. With regard to the municipal spatial policy, based primarily on records of planning documents, including a Study of the Conditions and Directions of Spatial Planning and a Zoning Plan, the issue of protection of cultural values and the landscape seems to have a significant impact. The lack

\section{WPROWADZENIE}

Polityka przestrzenna gmin, charakteryzowana przez pryzmat wartości historycznych i kulturowych oraz ochronę krajobrazu, w obowiązującym w Polsce systemie prawnym, oparta została przez ustawodawcę o treść ustawy o planowaniu i zagospodarowaniu przestrzennym [1] oraz ustawy Prawo budowlane [2]. Oba akty prawne, wraz z przepisami wykonawczymi, stanowią $\mathrm{w}$ Polsce fundamenty prawne procesu inwestycyjnego. W odniesieniu do polityki przestrzennej gmin, opartej przede wszystkim na zapisach dokumentów planistycznych, do których należą studium uwarunkowań i kierunków zagospodarowania przestrzen- 
of regulations on the obligation to implement, within statutory activities of public administration institutions (regional or municipal Restorer, Town/City Mayor) guideline documents, which indicate conditions for the development of municipalities, is highly negative for items requiring protection, and for the investment process. Acknowledging the legislators' view that the stage of agreement on a zoning documentation project, will verify the mentioned arrangements are a mistake. The complexity of the issues and the scope of the findings of planning documents indicate that the phase of implementing the mentioned documents containing condition-like elements should precede planning activities.

Regardless, land destination and restrictions on the land use are the foundation for spatial information, that undoubtedly affects the economic value of an area, determines the development of a region and results directly in the way of human functioning in terms of investment, economics, environmental protection, nature conservation, security, or the protection of the landscape and cultural values. The use of GIS technology in planning design, in the local, regional or national scale enables, considering the accessible information on land and its use, to develop simulations of individual variants of spatial development models (3D and 4D) while maintaining the principles of sustainable development and respect for natural resources and the cultural values. Such form of spatial planning also becomes a helpful tool in the presentation of planning solutions in public. GIS technology, as an integrated system of management and presentation of spatial data, can be a tool to solve problems and achieve a compromise. It is primarily due to the presentation of various studies results that take into account the aspects of space impossible to be presented in a 2D model (physiography, terrain models, technical infrastructure, formal considerations, landscape attractiveness, elements of spatial composition, a perception of cityscapes from certain viewpoints).

\section{LEGAL STATUS}

According to the Spatial Planning and Land Development Act [1], here referred to as the SPaLD Act, a study of the conditions and directions of spatial planning, as the document shaping the municipal spatial policy, shall take into account conditions arising in particular from: previous destination, land use and land utilities, spatial order and the requirements of its protection, the condition of the nego gminy oraz miejscowy plan zagospodarowania przestrzennego, problematyka ochrony wartości kulturowych i krajobrazu stanowi element mający dość znaczny wpływ. Brak prawnych uregulowań dotyczących obowiązku realizacji, w ramach działań statutowych poszczególnych instytucji administracji publicznej (wojewódzki lub miejski konserwator zabytków, wójt, burmistrz, prezydent miasta), dokumentów o charakterze wytycznych, stanowiących swego rodzaju wskazanie uwarunkowań dla kierunków rozwoju gmin, uznać należy za wysoce niekorzystny zarówno na przykład dla elementów wymagających ochrony, jak i dla samego procesu inwestycyjnego. Przyjęcie bowiem za ustawodawcą, iż etap uzgodnień projektu dokumentacji planistycznej zweryfikuje ostatecznie ustalenia w ww. zakresie jest błędem. Złożoność problematyki i zakres ustaleń dokumentów planistycznych wskazują, iż etap realizacji opracowań zawierających elementy stanowiące swego rodzaju uwarunkowania powinien wyprzedzać działania planistyczne.

Przeznaczenie terenu oraz obostrzenia dotyczące jego sposobu zagospodarowania stanowią fundament informacji przestrzennej, która niewątpliwie wpływa na wartość ekonomiczną przestrzeni, determinuje rozwój regionu, jak również przekłada się bezpośrednio na sposób funkcjonowania człowieka w rozumieniu inwestycyjnym, ekonomicznym, ochrony środowiska, ochrony przyrody, bezpieczeństwa czy ochrony krajobrazu i wartości kulturowych. Wykorzystanie technologii GIS w lokalnej, regionalnej czy krajowej skali projektowania planistycznego daje możliwość, przy uwzględnieniu dostępnych informacji o terenie i sposobie jego zagospodarowania, opracowania symulacji poszczególnych wariantów modeli (3D i 4D) zagospodarowania przestrzeni, z zachowaniem zasad zrównoważonego rozwoju i poszanowania zasobów naturalnych oraz zasobów stanowiących wartości kulturowe. Taka forma planowania przestrzennego staje się również pomocnym narzędziem $w$ procesie prezentowania rozwiązań planistycznych na forum publicznym.

Technologia GIS, jako zintegrowany system zarządzania i prezentacji danych przestrzennych, może stanowić narzędzie rozwiązania problemów oraz osiągnięcia kompromisu, głównie przez sposób prezentacji wyników określonych analiz, uwzględniających aspekty przestrzeni niemożliwe do zaprezentowania w modelu 2D (fizjografia, model terenu, infrastruktura techniczna, uwarunkowania formalnoprawne, atrakcyjność krajobrazowa, elementy kompozycji urbanistycznej, sposób odbioru panoram miasta z określonych punktów widokowych). 
environment, including, inter alia, the requirements of protecting the environment, nature, cultural landscape, the condition of cultural heritage and historical monuments and contemporary cultural property.

Given the findings of the study, it must be assumed that considering the issue of the landscape protection, it reflects the records of the Act on the protection and care of monuments [3]. It must be noted that article 145 of the mentioned act expands the scope of the arrangements introduced to a study by conservation protection authorities virtually without limitations. By making the character and scope of claims, regarding a planning document, dependent on the date of the founding of the municipal register of historical monuments.

The conclusions of the conservation protection services, required by law, collected in accordance with the SPaLD Act, containing cultural values and indicated an optimal way of protection, necessary to include in the study project, play a significant role in determining the municipal spatial policy that is included on the next stage of the study implementation $[4$, p. 6]. The same applies to the implementation procedure of the local zoning plan.

This is a direct cause of situations when under the Act on the protection and care of monuments, an assessment authority-a Restorer indicates that, in order to conform to applicable law, at the stage of implementation of the study, a study of the cultural landscape of the municipality should be drawn up as a supporting document. A cultural landscape, as defined in art. 3 point 14 of the Act on the protection and care of monuments is understood as space historically shaped as a result of human activity, including the creations of civilization and natural elements. According to the authority on the protection of monuments, the conclusions in the study of the cultural landscape of the municipality are required to be included in the study of the conditions and directions of the spatial planning of the municipality [5, p. 55-60].

The complexity of the issues of the protection of cultural landscape, the conclusions of monuments' protection services, on considering the work on the study of the cultural landscape protection while implementing the study, seem to be reasonable, regardless of the fact that the obligation of having the mentioned documents is considered to be illegal. It is far from being applicable to any laws.

\section{STAN PRAWNY}

Na podstawie zapisów ustawy o planowaniu i zagospodarowaniu przestrzennym [1], zwanej dalej ustawą o pizp, w studium uwarunkowań i kierunków zagospodarowania przestrzennego, jako dokumencie kształtującym kierunki polityki przestrzennej gminy, uwzględnia się uwarunkowania wynikające w szczególności z: dotychczasowego przeznaczenia, zagospodarowania i uzbrojenia terenu, stanu ładu przestrzennego i wymogów jego ochrony, stanu środowiska, w tym między innymi wymogów ochrony środowiska, przyrody i krajobrazu kulturowego, stanu dziedzictwa kulturowego i zabytków oraz dóbr kultury współczesnej.

Biorąc pod uwagę zakres ustaleń studium, przyjąć należy, iż w odniesieniu do tematyki związanej $\mathrm{z}$ ochroną krajobrazu jest on odzwierciedleniem zapisów zawartych w ramach ustawy o ochronie zabytków i opiece nad zabytkami [3]. Przy czym zaznaczyć należy, iż art. 145 ww. ustawy rozszerza zakres ustaleń wprowadzanych przez organy ochrony konserwatorskiej do studium praktycznie bez ograniczeń, uzależniając charakter i rozmiary roszczeń, w stosunku do dokumentu planistycznego, od terminu założenia gminnej ewidencji zabytków.

Ustawowo wymagane od służb ochrony konserwatorskiej wnioski, zbierane w myśl zapisów ustawy o pizp, zawierające konieczny do uwzględnienia w projekcie studium zasób wartości kulturowych i wskazany optymalny sposób jego ochrony, pełnią znaczącą rolę w określeniu polityki przestrzennej gminy uwzględnionej na kolejnym etapie realizacji studium [4, s. 6]. Podobnie rzecz się ma w przypadku procedury realizacji miejscowego planu zagospodarowania przestrzennego.

Przedstawiony stan jest bezpośrednią przyczyną sytuacji, w których, w myśl ustawy o ochronie zabytków i opiece nad zabytkami, organ opiniujący - konserwator zabytków - wskazuje, iż w celu dostosowania do obowiązujących przepisów prawa, na etapie realizacji studium, należy sporządzić dokument pomocniczy, jakim jest studium krajobrazu kulturowego gminy. Za krajobraz kulturowy, zdefiniowany w art. 3 pkt 14 ustawy o ochronie zabytków i opiece nad zabytkami, uznaje się przestrzeń historycznie ukształtowaną w wyniku działalności człowieka, zawierającą wytwory cywilizacji oraz elementy przyrodnicze. Zgodnie ze stanowiskiem organu ochrony zabytków, wnioski zawarte w studium krajobrazu kulturowego gminy mają obowiązek zostać uwzględnione w studium uwarunkowań i kierunków zagospodarowania przestrzennego gminy [5, s. 55-60]. 


\section{SPACE MANAGEMENT - MODEL 2D}

Poland is a country with a diversity of space functioning which is distinctive in Europe, but at the same time, with severe processes of spatial order and landscape physiognomy degradation and growing problems with management of cities and municipalities land use [6, pp. 5-18]. It is caused, inter alia, by the lack of clear assumptions indicating and interpreting ways of acting spaces eg. valuable culturally and historically, as well as the absence of a system of analysis and monitoring of changes in land development, taking into account the elements which are especially valuable and require protection. A way of regulating interactions plays a very important role in landscape systems. A mechanism based on an adaptation of the system to the conditions arising from changes in the environment, seems to be most appropriate. However, to make this mechanism work,a clear definition of the circumstances, indicating e.g., elements which must be regarded as protected, is necessary.

Management of space by planning for its way of use or protection requires access, and considering comprehensive and reliable information. Linking a number of databases and their correlation are the basis for the implementation of the analysis, then creating variants of the solutions and modeling changes in space, finally monitoring its transformations over time.

The records of planning documents for the city of Zielona Góra of 2015 can be an example of thinking about space limited to $2 \mathrm{D}$ model. Based on the findings of the study of the conditions and directions of the city spatial planning (Fig. 1),a zoning plan has been developed (Fig. 2), concerning with its arrangements, a part Zielona Góra center, including the area which covers quarters adjacent directly to the old market. The north frontage of Konstytucji 3 Maja street was characterized by the view into the W. Sikorskiego street ended by dominating tower of the City Hall (Fig. 3). The introduction of the detailed findings of the plan and the arrangements on the obligatory course of buildings and the maximum height of buildings, but without a broader analysis, in this case concerning the terrain, the relative height of buildings, or the composition of urban planning, has led to the accomplishment of the Kepler's Science Center project, losing completely the original layout of W. Sikorskiego street (Fig. 4). The above example indicates a strong correlation between spatial policy document and a local law. Effects of negligence or lack of relevant studies seem irreversible.
Złożoność problematyki związanej z ochroną krajobrazu kulturowego oraz wnioski służb ochrony zabytków, dotyczące uwzględnienia w ramach realizacji studium wyników prac nad studium ochrony krajobrazu kulturowego, wydają się być jak najbardziej uzasadnionymi, niezależnie od faktu, iż procedurę wymagalności tych dokumentów uznać należy za bezprawną. Niepoparta jest ona bowiem żadnym z obowiązujących przepisów prawa.

\section{ZARZAZDZANIE PRZESTRZENIA - MODEL 2D}

Polska jest krajem o wyróżniającej się w Europie różnorodności sposobu funkcjonowania przestrzeni, ale jednocześnie o bardzo nasilonych procesach degradacji ładu przestrzennego i fizjonomii krajobrazu oraz narastających problemach zarządzania zagospodarowaniem obszarów miast i gmin [6, s. 5-18]. Przyczyną takiego stanu jest między innymi brak jasnych założeń wskazujących i interpretujących sposób działania przestrzeni, np. cennych kulturowo i historycznie, a także brak systemu analiz i monitorowania zmian w zagospodarowaniu przestrzeni, przy uwzględnieniu elementów szczególnie cennych i wymagających ochrony.

Bardzo ważną rolę w systemach krajobrazowych odgrywa sposób regulacji wzajemnych oddziaływań. Mechanizm oparty na adaptacji dostosowującej system do warunków wynikających ze zmian zachodzących w otoczeniu wydaje się najwłaściwszy.

Aby jednak ten mechanizm zadziałał, potrzebna jest jasno określona definicja uwarunkowań wskazujących na przykład na to, które elementy bezwzględnie należy uznać za podlegające ochronie.

Zarządzanie przestrzenią przez planowanie jej sposobu zagospodarowania lub ochrony wymaga dostępu oraz uwzględnienia wszechstronnej i wiarygodnej informacji. Powiązanie ze sobą szeregu baz danych i ich wzajemna korelacja stanowią podstawę do realizacji analiz, następnie tworzenia wariantów rozwiązań i modelowania zmian zachodzących w przestrzeni, aż po możliwość monitorowania jej przekształceń w czasie.

Przykładem sposobu myślenia o przestrzeni, w ograniczonym do modelu 2D systemie, mogą być zapisy dokumentów planistycznych dla miasta Zielona Góra z 2015 r. Na podstawie ustaleń studium uwarunkowań i kierunków zagospodarowania przestrzennego miasta (rys. 1) opracowany został miejscowy plan zagospodarowania przestrzennego (rys. 2), obejmujący swoimi ustaleniami część śródmieścia miasta Zielona Góra, w tym obszar, w skład którego wchodzą kwartały sąsiadujące bezpośrednio ze Starym Rynkiem. Widok wnętrza ulicy W. Sikorskiego zakończony dominantą w po- 


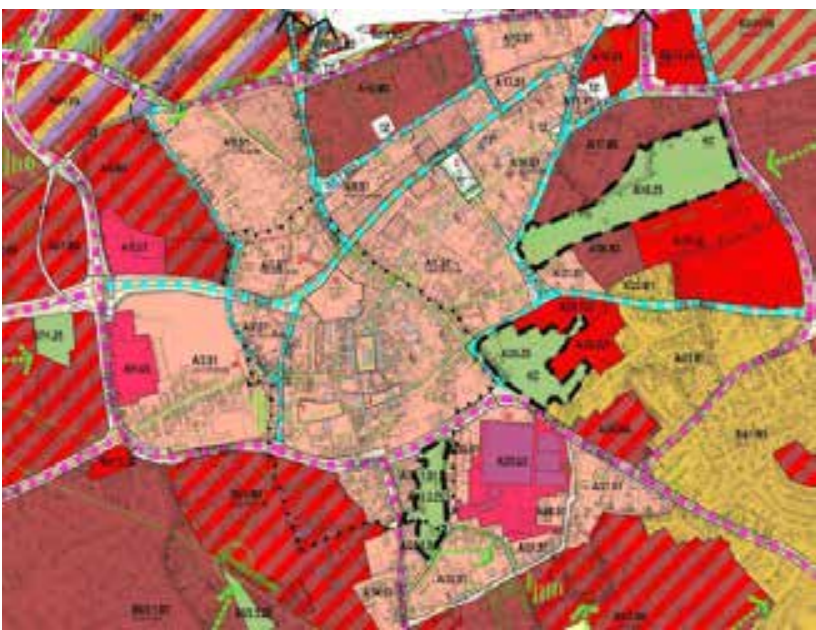

Fig. 1. Map extract from the study of the conditions and directions of spatial planning of Zielona Gora [7]

Rys. 1. Wyrys ze studium uwarunkowań i kierunków zagospodarowania przestrzennego miasta Zielona Góra [7]

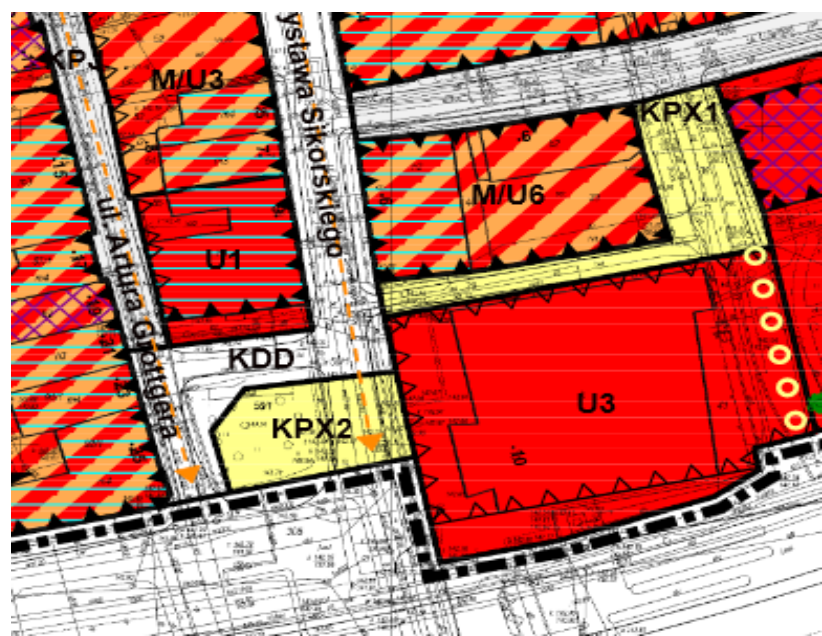

Fig. 2. Map extract from the local plan of land use in Zielona Góra - Śródmieście 9 [8]

Rys. 2. Wyrys z miejscowego plan zagospodarowania przestrzennego w Zielonej Górze - Śródmieście 9 [7]

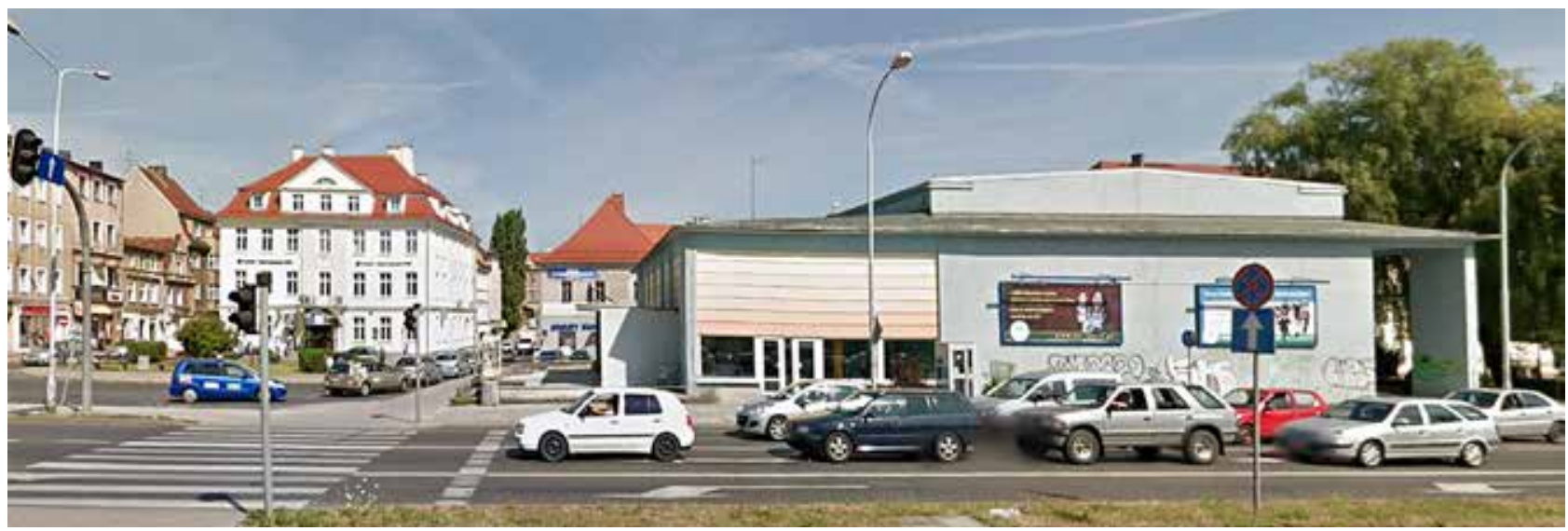

Fig. 3. View of the Town Hall from the side of Gen. W. Sikorskiego street in Zielona Gora. Year 2013. Source: https://www. google.pl/maps/@51.935545,15.506222,3a,75y,90t/data=!3m4! 1e1! 3 m 2! 1sSa2oUtzSsKGwmXXIRaXZUQ! 2e0, date of access: 14.05.2015)

Rys. 3. Widok na wieżę Ratusza od strony ul. gen. W. Sikorskiego w Zielonej Górze. Rok 2013. Źródto: https://www. google.pl/maps/@51.935545,15.506222,3a,75y,90t/data=!3m4!1e1!3m2!1sSa2oUtzSsKGwmXXlRaXZUQ!2e0, data dostępu: 14/05.2015r.)

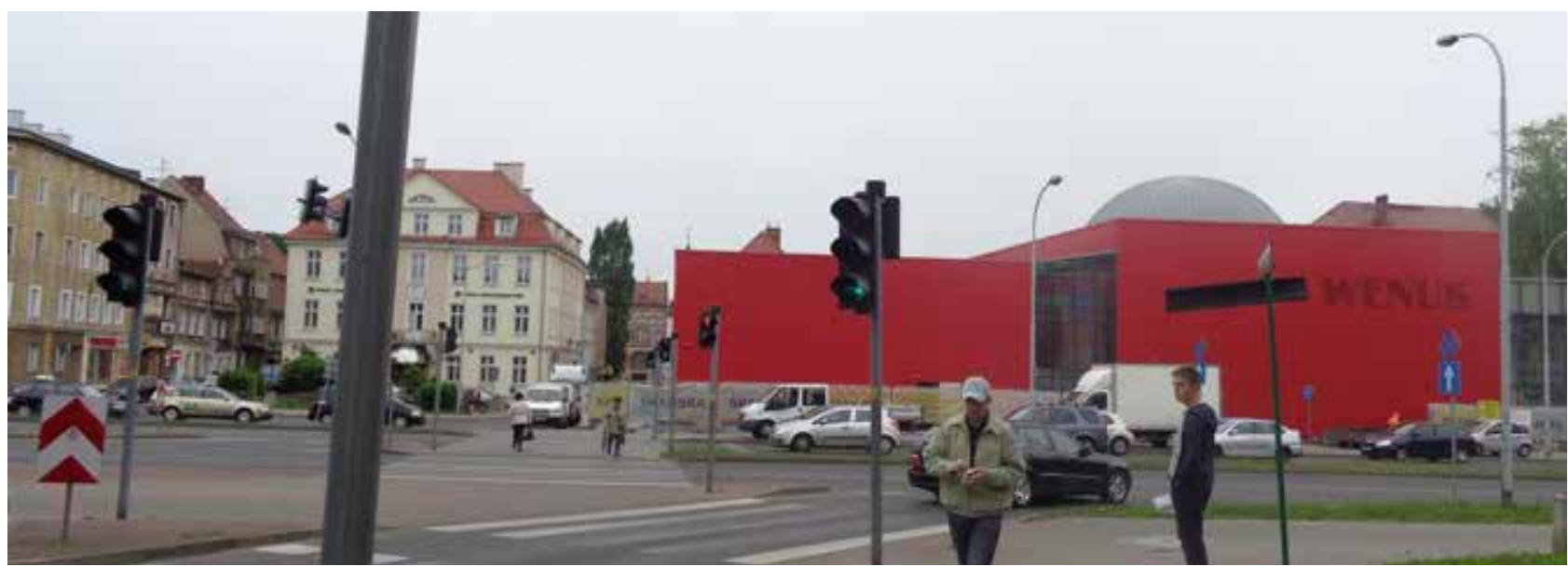

Fig. 4. View of the Town Hall from the side of Gen. W. Sikorskiego street in Zielona Góra. Year 2015. Source: author Rys. 4. Widok na wieżę Ratusza od strony ul. gen. W. Sikorskiego w Zielonej Górze. Rok 2015. Źródto: autor 


\section{EXAMPLE OF THE USE OF GIS TECHNOLOGY - 3D MODEL}

Taking into account the development of GIS technology, the use of its capabilities in spatial policy and space management seems inevitable. Implementation of the zoning plan, limited only to legalizing new investment should be in the present state of knowledge, treated as an abuse in relation to the public space owned by its users- residents. The perception of an object due to its relationship with the environment, mainly through the financial implications related to the execution of a planning document, should be one of the elements affecting the final location decision.

Analysis of effects and aspects of the spatial implementations of individual investments in internal or external views rendering panorama layout, using GIS models (3D) seem to be already an indispensable a tool to help in the selection of the most advantageous variant of the space management. Selection of views and indicating viewpoints, topographical analysis of land, protection of open and closed landscapes, height of buildings and its harmonious combination with greenery complemented by architectural accents, identifying and distinguishing the space [9], enable to analyze the properties of space in a way incomparable to the 2D model (Fig. 5 and Fig. 6).

Local law, also regarding municipal spatial policy, is next to common law, the most important tool for the implementation of, inter alia, the protection of cultural heritage. To ensure the effectiveness of these activities, it is necessary to take an attitude that the protection of cultural values, including the cultural landscape is

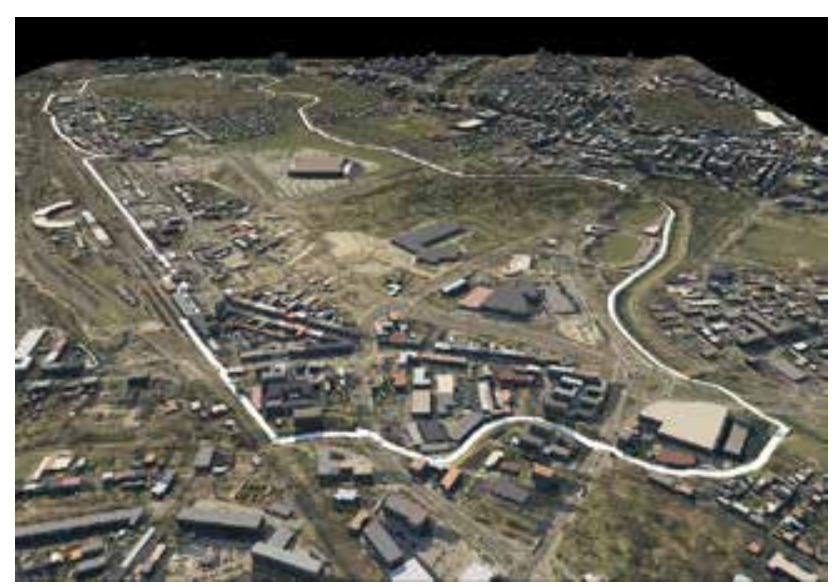

Fig. 5. Analysis of the terrain and the height of the citymodel 3D. Source: PA Nova S.A.

Rys. 5. Model uksztattowania terenu i wysokości zabudowy. Źródto: PA Nova S.A. staci wieży Ratusza charakteryzował pierzeję północną ulicy Konstytucji 3 Maja (rys. 3). Wprowadzenie ustaleń szczegółowych planu miejscowego, jak i ustaleń dotyczących przebiegu obowiązującej zabudowy oraz wysokości maksymalnej budynków, jednak bez szerszych analiz dotyczących w tym wypadku ukształtowania terenu, wysokości względnych budynków czy elementów kompozycji urbanistycznych, doprowadziło w konsekwencji do realizacji obiektu Centrum Nauki Keplera, zaburzając całkowicie pierwotny układ ulicy W. Sikorskiego (rys. 4). Przykład ten wskazuje na silne współzależności między dokumentem polityki przestrzennej a prawem lokalnym. Skutki niedopatrzenia lub braku stosownych analiz wydają się nieodwracalne.

\section{PRZYKEAD WYKORZYSTANIA TECHNOLOGII GIS - MODEL 3D}

Biorąc pod uwagę rozwój technologii GIS, wykorzystanie jej możliwości w polityce przestrzennej i systemie zarządzania przestrzenią wydaje się nieuniknione. Realizacja planu miejscowego w mieście, ograniczona jedynie do zalegalizowania nowo powstającej inwestycji, powinna być w obecnym stanie wiedzy traktowana jako nadużycie $\mathrm{w}$ odniesieniu do przestrzeni publicznej, której właścicielami są jej użytkownicy - mieszkańcy. Postrzeganie obiektu ze względu na jego relacje $\mathrm{z}$ otoczeniem, głównie za sprawą skutków finansowych związanych $\mathrm{z}$ realizacją dokumentu planistycznego, powinno stanowić jeden z elementów wpływających na ostateczną decyzję lokalizacyjną.

Analizy aspektów i skutków przestrzennych realizacji poszczególnych inwestycji w widokach wewnętrznych czy też zewnętrznych wnętrz urbanistycznych eksponujących panoramę układu, przy wykorzystaniu modeli GIS (3D), wydają się być już dzisiaj nieodzownym narzędziem, pomocnym w wyborze najkorzystniejszego wariantu zagospodarowania przestrzeni. Selekcja widoków i wyszczególnienie punktów widokowych, analiza topograficzna terenu, ochrona krajobrazów otwartych i domkniętych, wysokość zabudowy i jej harmonijne połączenie z zielenią, uzupełnione przez akcenty architektoniczne, wyróżniające i identyfikujące przestrzeń [9], dają możliwość analizy właściwości przestrzeni w sposób niewspółmierny do modelu 2D (rys. 5 i rys. 6).

Prawo miejscowe, w tym odnoszące się do polityki przestrzennej gminy, jest obok prawa powszechnego najważniejszym narzędziem realizacji między innymi ochrony dziedzictwa kulturowego. Dla zapewnienia skuteczności działań niezbędnym jest przyjęcie sposobu myślenia, w ramach którego ochrona warto- 


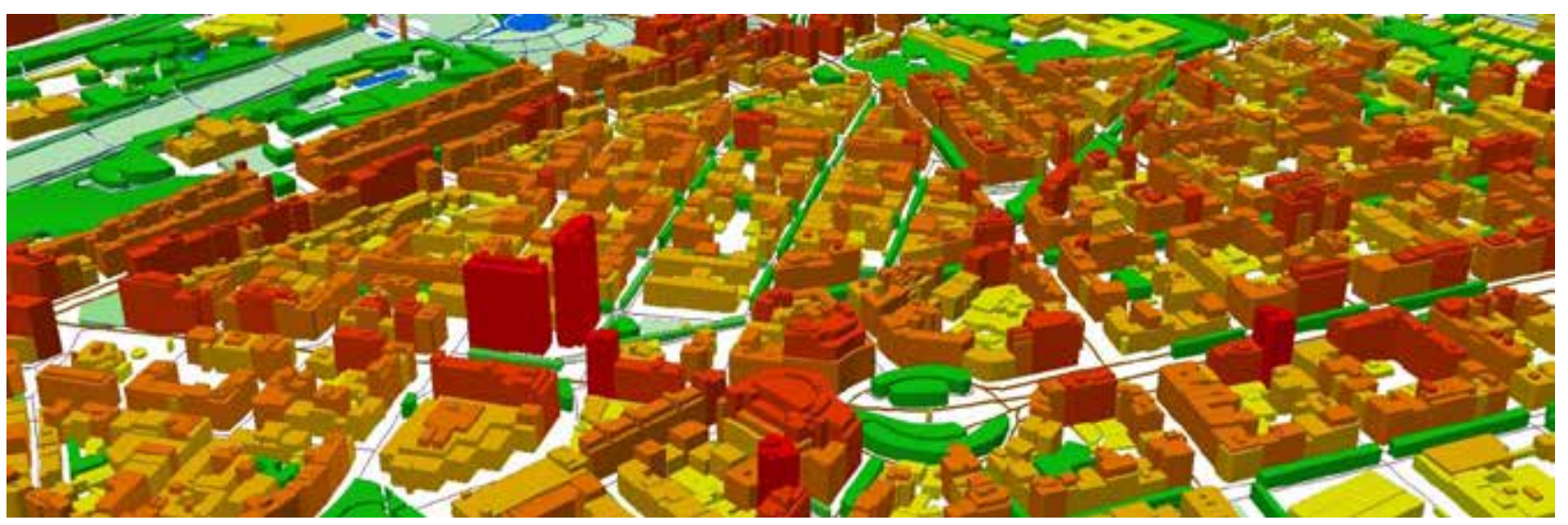

Fig. 6. Analysis of the topographical model of the city and the height of buildings. Source: http://fotogrammetrik.com/pl/uslugi/ Rys. 6. Model topograficzny miasta i wysokości zabudowy. Źródto: http://fotogrammetrik.com/pl/uslugi/

an important public interest, and the element of the sustainable development of the municipality. Such type of thinking indicates the need for an extension of the social participation and involvement, as a local group in the processes of creating a local law in the name of protection of common interests that is, local identity. In this case, using the GIS model (3D), inter alia, through presentations and data generation, offers great possibilities regarding a problem of social participation in land-use planning.

Given the above, it should be assumed that a local zoning plan, as a local law, can be seen as a cultural or urban landscape protection tool, despite the corrections in the rules of law, provided that the execution will be preceded by efforts to identify conditions and conclusions of the analysis carried out to optimize land use, taking into account the traditions of the place or the needs of the inhabitants, and the relationship between urban structure and the surrounding undeveloped land will be shaped in accordance with the logic of spatial systems. Along with the development of measurement techniques, that enable fast acquisition of 3D model data (in this case, the individual buildings and spatial elements) and linking them with the descriptive data base, becomes a helpful tool in spatial planning at the socalled intelligent urban development $[11,12]$.

\section{CONCLUSIONS}

It seems that, regarding a process of designing planning documents, a requirement for studies like landscape study or landscape plans, following the example of Germany or the UK, is an obligation. These documents, as starting materials for planning studies, implemented on the basis of executory orders, along with the eco-physiography, or forecasts ści kulturowych, w tym krajobrazu kulturowego, stanowi ważny interes publiczny, a tym samym element zrównoważonego rozwoju gminy. Tego typu myślenie wskazuje na potrzebę rozszerzenia partycypacji społecznej i zaangażowania społeczeństwa, jako grupy lokalnej, w procesy tworzenia prawa lokalnego w imię ochrony wspólnych interesów, a tym samym tożsamości lokalnej. Wykorzystanie w tym przypadku modelu GIS (3D), między innymi przez sposoby prezentacji i generowania danych, daje ogromne możliwości w odniesieniu do problemu partycypacji społecznej w planowaniu przestrzennym.

Przyjąć należy, iż miejscowy plan zagospodarowania przestrzennego, jako prawo miejscowe, może być rozpatrywany w kategorii narzędzia ochrony krajobrazu kulturowego czy urbanistycznego, niezależnie od korekt w obowiązujących przepisach prawa, pod warunkiem że jego realizację poprzedzą działania mające na celu wskazanie uwarunkowań i wniosków z przeprowadzonych analiz, skutkiem których będzie optymalizacja zagospodarowania przestrzeni z uwzględnieniem tradycji miejsca i potrzeb samych mieszkańców, a sam związek struktury zespołu urbanistycznego z otaczającym terenem niezabudowanym, kształtowany będzie zgodnie z logiką układów przestrzennych.

Wraz z rozwojem technik pomiarowych, pozwalających na szybkie pozyskanie danych modelowych 3D, $\mathrm{w}$ rozpatrywanym przypadku poszczególnych budynków i elementów przestrzennych, oraz powiązanie ich $z$ danymi baz opisowych, staje się pomocnym narzędziem w planowaniu przestrzennym przy tzw. inteligentnym rozwoju miast $[11,12]$.

\section{WNIOSKI}

Wydaje się, że obowiązkowym, z punktu widzenia procesu projektowego dokumentów planistycznych, 
of impacts of the plan on the environment, may become guidelines to a plan or a study. They may stress the importance of such things as: nature and landscape values protection(use of land zones requires specifying rules for maintenance of the landscape characteristics and forms), conservatory protection zones (panoramas protection, monument or area exposure zone protection, designation of areas excluded from development on the basis of observation analyses which also determine zoning and land use), or areas of cultural values protection zones (rural and urban, clear spatial structure building and greenery areas).

From the above point of view, the content of the applicable law on municipal spatial policy, considering solutions that affect the space functioning, including forms depicting cultural values,taking into account their mutual ties and the feasibility of the introduced documents, is only an introduction to a discussion on space. Local plan, just like a building, reflects the state of civilization. It is important, however, not to lose in its content the goal of respect for cultural values, that is a respect for the users of the space to which it applies.

It is important that local plans, as tools for spatial policy in a municipality, are constructed competently, and used properly. Local plans considering: nonexistent in the current legislation e.g. cultural landscape studies indicating cultural heritage protection by area with the use of panoramas, viewpoints, foreground protection. Planning documents pointing out the elements of space such as wooded areas, alleys, or lines of trees. Development composition, taking into account the density and intensity, based on the grid of streets characteristic for the area, including thinking about communication, as a system.

GIS technology-3D and 4D models offer great opportunities for data access and analysis for decisions about the directions of the development of urban systems. Techniques of coordination of knowledge resulting from the data analysis and building models of potential solutions associated, e.g. with the economic aspects of this type of activity, or practice activities based on consensus, seem appropriate approach to spatial planning, which also allows time monitoring of changes in space cities. Cadastral systems, using the GIS applications can be found in a variety of applications-however, the 3D and 4D techniques allow present data and visualize models giving the potential to improve space jest wymagalność realizacji opracowań typu studium krajobrazu czy planów krajobrazu, idąc za przykładem Niemiec czy Wielkiej Brytanii. Dokumenty te, na zasadzie materiałów wyjściowych do opracowań planistycznych, realizowane na podstawie rozporządzeń wykonawczych do obowiązujących ustaw razem z ekofizjografią czy prognozą skutków wpływu ustaleń planu na środowisko, mają szansę, jako wytyczne do planu czy studium, podkreślić wagę takich elementów przestrzeni, jak: ochrona przyrody i walorów krajobrazowych (zagospodarowanie stref wymaga określenia zasad utrzymania cech i form krajobrazu), stref konserwatorskich ochrony ekspozycji (ochrona panoram, stref ekspozycji zabytku czy obszaru, wyznaczenie terenów wyłączonych spod zabudowy na podstawie analiz widokowych określających równocześnie warunki zabudowy i zagospodarowania terenu) czy strefy ochrony obszarów przedstawiających wartości kulturowe (układy ruralistyczne i urbanistyczne, zespoły zabudowy i zieleni o czytelnej strukturze przestrzennej).

Wychodząc z powyższego punktu widzenia, treść obowiązujących przepisów prawa w odniesieniu do polityki przestrzennej gmin, uwzględniającej rozwiązania wpływające na sposób funkcjonowania przestrzeni, w tym form przedstawiających wartości kulturowe, przy uwzględnieniu ich wzajemnych powiązań oraz wykonalności wprowadzanych nimi dokumentów, stanowi jedynie wstęp do rozważania o przestrzeni. Plan miejscowy, podobnie jak obiekt budowlany, stanowi odzwierciedlenie stanu systemu cywilizacyjnego. Ważnym jest jednak, aby nie zatracił w swej treści celu, jakim jest poszanowanie wartości kulturowych, a tym samym poszanowanie użytkowników przestrzeni, której dotyczy.

Istotnym jest, by plany miejscowe, jako narzędzie polityki przestrzennej w gminie, były właściwie konstruowane i wykorzystane. Powinny one uwzględniać, nieistniejące w obecnym stanie prawnym np. studia krajobrazu kulturowego, wskazujące na obszarową ochronę dziedzictwa kulturowego z wykorzystaniem formy, jaką jest ochrona: panoram, ekspozycji widokowych, czy przedpola. Dokumenty planistyczne powinny uwzględniać $w$ ramach swoich ustaleń elementy przestrzeni typu: zadrzewienia, aleje, czy szpalery drzew. Kompozycja zabudowy wskazywana w planach odnosić powinna się z większym poszanowaniem wskaźników typu: gęstość, chłonność, chropowatość i intensywność zabudowy, nie pomijając myślenia o strukturze urbanistycznej, opartej na charakterystycznej dla danej przestrzeni siatce ulic, z uwzględnieniem komunikacji, jako jednego z systemów przestrzeni zurbanizowanej. 
management system, and thus also the possibility of elimination of mistakes in spatial planning at the stage of analysis and modeling. That seems to be a particularly valuable aspect,due to the fact that planning decisions determine a city function in a virtually unrecoverable way.
Technologia GIS - modele 3D i 4D - dają duże możliwości dostępu do danych oraz analiz na potrzeby decyzji dotyczących kierunków rozwoju systemów miejskich. Techniki koordynacji wiedzy wynikającej $\mathrm{z}$ analiz danych oraz budowanie modeli potencjalnych rozwiązań powiązanych na przykład z ekonomicznymi aspektami tego typu działalności czy też praktyka działań oparta na konsensusie, wydaje się adekwatnym do problematyki planowania przestrzennego podejściem, umożliwiającym również monitorowanie $\mathrm{w}$ czasie zmian zachodzących w przestrzeni miast. Systemy katastralne wykorzystujące aplikacje GIS można znaleźć w różnych aplikacjach - jednak technika 3D i 4D pozwala na prezentację danych i wizualizację modeli, dając potencjał do poprawy systemu zarządzania przestrzenią, a tym samym również możliwości eliminacji ewentualnych błędów w planowaniu przestrzennym na etapie analiz i modelowania, co wydaje się szczególnie cennym aspektem, biorąc pod uwagę fakt, iż decyzje planistyczne przesądzają o sposobie funkcjonowania przestrzeni miasta w sposób praktycznie nieodwracalny.

\section{References}

[1] The act of 27 March 2003 on spatial planning and development (Off. J. of 2015 item 199 as amended).

[2] The Act of 7 July 1994-construction law (Off. J. of 2013 item 1409 as amended).

[3] The Act of 23 July 2003. on the protection and care of monuments (Off. J. of 2003. no 162, item. 1568- as amended).

[4] Welc-Jędrzejewska J., Kulesza-Szerniewicz E., Makowska B., Stieler E., Jagielska E., Wnioski w zakresie ochrony dziedzictwa kulturowego i zabytków do projektów studiów uwarunkowań i kierunków zagospodarowania przestrzennego gmin i projektów miejscowych planów zagospodarowania przestrzennego, Kurier Konserwatorski, Nr 4, 2009.

[5] Bazan-Krzywoszańska A., Ochrona krajobrazu w aspektach rozwoju źródet energii odnawialnej i polityki przestrzennej gmin, na przyktadzie gminy Krotoszyce, Architektura Krajobrazu: Studia i prezentacje, nr 3, 2012, s. 55-60.

[6] Chmielewski T.J., Wyzwania zarzadzania systemami krajobrazowymi w Polsce, Problemy Ekologii Krajobrazu, Vol XXXV, 2013, p. 5-18, http://paek.ukw.edu.pl/pek/index.php/PEK/article/viewFile/31/11> [dostęp: 01.07.2017].

[7] The study of the conditions and directions of the spatial planning of Zielona Góra, adopted by the resolution of Zielona Góra City Council No. XVIII.139.2015 of 30 June 2015, http://www.zielona-gora.pl/binary/planowanie/ zm_studium_2015.jpg, [access: 19.07.2015].

[8] Zoning plan in Zielona Gora-Śródmieście (Downtown) 9, adopted by resolution of the City Council of Zielona Góra No. LXXIX. 709.2014 of 23 December 2014, http://dzienniki.luw.pl/ActDetails.aspx?year=2014\&book=0\&poz=2464 [access: 19.07.2015].

[9] Czyńska K., Zabudowa wysoka a harmonijne ksztaltowanie krajobrazu miejskiego, http://www.pif.zut.edu.pl/pif13_pdf/D-02_Czynska.pdf [access:01.07.2017].

[10] Kowalska-Jamrożek D., Wykorzystanie aplikacji GIS w planowaniu przestrzennym Kielc, Miejski System Informacji Przestrzennej w Kielcach, Biuro Planowania Przestrzennego Urzędu Miasta w Kielcach, http://www.um.kielce.pl/ gfx/kielce2/userfiles/images/gis/aktualnosci/2010_11_18/dominika_kowalska.pdf [access: 01.07.2017].

[11] Miller J.S., Hoel L.S., The „smart growth” debate: best practices for urban transportation planing, Socio-Economic Planning Sciences, (36) 2002, pp. 1-24.

[12] Guo R. et al., Developing a 3D cadastre for the administration of urban land use: A case study of Shenzhen, China, Computers, Environment and Urban Systems, (40) 2013, pp. 46-55.

[13] Guney C. et al., Tailoring a geomodel for analyzing an urban skyline, Landscape and Urban Planning, (105) 2012, pp. 160-173.

Acknowledgments:

The work was financed by the University of Zielona Gora as part of the statutory work No. 220570/E-545/S/2017
Podziękowania:

Praca finansowana przez Uniwersytet Zielonogórski w ramach pracy statutowej $n r: 220570 / E-545 / S / 2017$ 